Topics of public concern arising from recent medical advances are given an airing in the British Association's most recent publication, Social Concern and Biological Advances (British Association, 50p).

A wide-ranging committee of scientists, lawyers, Members of Parliament, theologians and others was set up in 1972 to investigate the social, ethical and legal implications of certain medical advances, notably those in the fields of in vitro fertilisation and genetic manipulation.

Discussing artificial insemination by donor (AID) the committee consider that the legal status of any child conceived through AID needs to be properly defined as such children now occupy a twilight sub-legal zone. The genetic makeup of the donor is another important issue, and the committee call for a decision as to whether prospective sperm donors should be examined medically and as far as it is possible, genetically. The control of sperm storage banks is another problem of some concern. The government should decide immediately whether private banks are to be allowed and standards and supervision for such banks should be defined.

The committee recommends that research on in vitro fertilisation should continue as its possible advantages outweigh potential disadvantages. But there is the potential for abuse, and so the medical profession and government should keep a careful eye on new developments in this field and should be prepared to act quickly to prevent abuse.

Genetic screening for some genetic-

ally determined crippling diseases is now relatively common. Although this reducing the numbers of children born with severe mental and physical abnormalities, the moral problems at both the social and personal levels can cause acute distress.

Social attitudes towards abortion can influence both the doctor's recommendation and the mother's response

\section{Biomedical advances give rise to concern}

when an abnormality it detected especially in borderline cases where the degree of the abnormality cannot be predicted precisely. Less obvious but equally distressing, is the risk that a woman carrying an affected foetus could be subjected to social censure if she refused to be screened or undergo an abortion. This censure could also carry over to the child itself.

Under the broad heading of genetic engineering, eugenics and pre-natal sexing, the committee considers gene therapy, potentially useful but still experimental; sterilisation of people carrying defective genes; and the possibility of being able to choose the sex of one's child.

A policy of selective sterilisation needs to be scrutinised particularly carefully, as individual rights must be protected and the definition of "normality' can be open to abuse by political and social systems which seek to manipulate it for their own ends. The committee make no specific recommendations on this head but advise continuing review of developments in this field.

The committee seem undecided as to whether pre-natal sexing will have much appeal for Western societies but recommend that official bodies should be prepared to act quickly to prevent precipitous and unadvised applications of new sex selection procedures.

The report also covers the chief moral problems involved in organ transplantation such as defining the moment of death and the ownership of the dead body. "Any definition of death" it says, "implies an understanding of what constitutes life".

The 1961 Human Tissues Act covers the transplantation of organs but is unsatisfactory on some points. Under this Act the legal possessor of the dead body can authorise the removal of the organs. But who, asks the committee, is the legal possessor, and what constitutes a reasonable inquiry to gain permission from relatives to remove organs for transplantation? Also, should Britain operate a "contracting in" or a "contracting out" system whereby people indicate whether or not they wish their organs to be used after death?

The committee favour adopting some of the recommendations of the 1969 McLennan Committee. These are that the present system should stand but that it needs legal reinterpretation to remove ambiguities and to facilitate the supply of organs to transplantation. Registers should be kept both of those who wish to contract out, and on the other side of the coin, those who specifically wish to donate organs after their death should also be registered.

\section{of urban transport.}

In Germany 45 miles of test track are now planned at a site near Augsburg and very large public sums ( $£ 100 \mathrm{~m}$ for $\mathrm{R}$ and $\mathrm{D}$ alone) have been invested in high speed transport for the future with particular emphasis going to linear motor development and magnetic levitation. Krauss Maffei which won the contract for the Toronto project at about the period that the Government announced the cancellation of the tracked hovecraft has switched its design from the 'conventional' doublesided linear motor to the single-sided type first conceived by Professor Laithwaite and 'proved' on the THL vehicle which Krauss Maffei had visited.

In the light of this amount of world activity and interest the ostensible reason for last year's Government cancellation of the tracked hovercraft, that there was no customer or market for it, seems extraordinarily thin. In fact some of the by-products of THL -the single-sided linear induction motor, the box-beam track for instance -have, as described, been adopted in overseas projects. The Select Committee accepted that Britain had about a five-year lead in overall hovertrain technology-and this was being reflected in consultancy fees particularly in North America. Professor Laithwaite's even more recent breakthrough which he calls the 'magnetic river' and which offers propulsion and controlled suspension in three axes from the same transverse-flux linear motor running on normal mains $\mathrm{AC}$ seems to put British research in the field of high speed transport even further ahead. Professor Laithwaite claims that he will have a production prototype of this double-purpose motor within six months, and it is particularly suitable for speeds of over $250 \mathrm{mph}$ (where British Rail's APT runs out). Similar claims for the University of Sussex electro-magnetic attraction system, recently demonstrated in an urban passenger carrying version being devoloped for a $2 \frac{1}{2}$-mile shuttle along Brighton front, seem likely to be misplaced. Over $50 \mathrm{mph}$, a serious drag, develops from eddy-currents set up in the track (a problem that Krauss Maffei are encountering in the Toronto project now). One is forced to believe that the only customers that the British Government's chief scientist departments accept are home customers and that in the case of the tracked hovercraft it was especially unfortunate that the customer department DoE was also the sponsoring department of British Rail and its pet the APT. Customers beyond 1985 are not being considered and their seems no mechanism for considering the general public as a customer.

The Government has turned down the Imperial College form of proposal for keeping the Earith test track in being. Several practical problems now arise. The estimated cost of dismantling the track is $£ 200,000$ and THL has no funds left so the Government will 